\title{
Identification of Pantoea stewartii subsp. stewartii by PCR and Strain Differentiation by PFGE
}

David L. Coplin and Doris R. Majerczak, Department of Plant Pathology, The Ohio State University, Columbus 43210-1087; and Yongxiang Zhang, Won-Sik Kim, Susanne Jock, and Klaus Geider, Max-Planck-Institut für Zellbiologie, Rosenhof, D-68526 Ladenburg, Germany

\begin{abstract}
Coplin, D. L., Majerczak, D. R., Zhang, Y., Kim, W.-S., Jock, S., and Geider, K. 2002. Identification of Pantoea stewartii subsp. stewartii by PCR and strain differentiation by PFGE. Plant Dis. 86:304-311.

Stewart's bacterial wilt and leaf blight of sweet corn and maize is caused by Pantoea stewartii subsp. stewartii. This bacterium can be seed transmitted at a low frequency, so it is subject to quarantine restrictions by many countries. To develop a polymerase chain reaction assay for the identification of this pathogen from field samples and for use in seed health tests, four primer pairs were tested. These were selected from the sequences of hrpS, cpsDE, and the 16S rRNA intergenic transcribed spacer (ITS) region. Under optimal reaction conditions, about 20 and 200 cells of $P$. stewartii could be detected in pure cultures and leaf lesions, respectively. Other plantassociated enteric bacteria (e.g., P. agglomerans pv. herbicola, P. ananas, Erwinia amylovora, and $E$. carotovora) either did not produce amplicons or they were not the correct size for $P$. stewartii. To test further for possible false positives, 29 yellow-pigmented bacteria, mainly other Pantoea spp., were isolated from lesions on old corn leaves and assayed with the ITS primer sets. Except for weak, variable reactions with three $P$. ananas strains, the bacteria did not test positive. Pulsed field gel electrophoresis (PFGE) was evaluated as an additional test to confirm the identity of $P$. stewartii. After digestion with SpeI and XbaI, P. stewartii strains could be easily distinguished from related Erwinia and Pantoea spp. and each other.
\end{abstract}

Additional keywords: cps, Erwinia stewartii, hrp, Pantoea ananas, RFLP

Pantoea stewartii subsp. stewartii (syn. Erwinia stewartii [24] and hereafter referred to as $P$. stewartii) causes Stewart's vascular wilt and leaf blight of sweet corn and maize, a bacterial disease that is responsible for serious crop losses. The disease is spread by the corn flea beetle Chaetocnema pulicularia (28), but can be seed transmitted at a very low frequency $(6,7,25)$. However, the potential risk of seed transmission is considered so important in international shipment of corn seed that more than 50 countries ban its import unless it is certified to be free of $P$. stewartii. The traditional techniques for detection and identification of $P$. stewartii include field inspection of plants to be harvested as seed, grow-out tests of seed, and an enzyme-linked immunosorbent assay (ELISA; 22). These assays are time

Corresponding author: D. L. Coplin

E-mail: coplin.3@osu.edu

Salaries and research support for D. L. Coplin and D. R. Majerczak were provided by State and Federal funds appropriated to the Ohio Agricultural Research and Development Center, The Ohio State University.

Accepted for publication 13 November 2001.

Publication no. D-2002-0123-02R

(c) 2002 The American Phytopathological Society consuming and relatively insensitive. A polymerase chain reaction (PCR)-coupled ligase chain reaction (LCR) test (30) has been demonstrated to identify the pathogen. However, the use of radioisotopes limits this method for routine assays. A specific, two-step PCR detection method for P. stewartii was developed by Blakemore et al. (4). This test uses nested primers complementary to a diagnostic DNA hybridization probe that was generated by arbitrarily primed PCR (5).

There are two major gene clusters that play an important role in the pathogenicity and virulence of $P$. stewartii: (i) the cps gene cluster, which is required for production of the exopolysaccharide (EPS) stewartan (13); and (ii) the hrp gene cluster, which encodes a type-III secretion system that is necessary for general pathogenicity and the production of water-soaked lesions $(10,11,19)$. Stewartan consists of a sevenmonosaccharide repeating unit that contains glucose, galactose, and glucuronic acid. The cps gene cluster comprises 12 genes, $\cos A$ to $c p s M$, that encode proteins for the assembly and secretion of the repeating units and their polymerization into a macromolecule (13). The genetic organization of the P. stewartii cps cluster is very similar to that of the E. amylovora ams gene cluster, which is responsible for the synthesis of amylovoran EPS $(3,9)$. Consequently, amylovoran is very similar in structure to stewartan (3) and differs in only two sugar residues. These changes are accounted for by three glycosyl-transferase genes that differ between the ams and cps clusters (14). One of these is cpsD. The hrp gene cluster of $P$. stewartii is homologous to that of E. amylovora (19) and $P$. agglomerans pv. gypsophilae (26). It consists of seven complementation groups, plus a linked disease-specific effector region. Gene $h r p S$ (formerly wtsA) encodes an NtrC-like transcriptional enhancer that is required for the expression of hrp secretion and wts effector genes and shares significant similarity to the central domains of $P$. syringae pv. phaseolicola and E. amylovora hrpS $(19,20)$.

Pulsed field gel electrophoresis (PFGE) separates large restriction fragments created by digestion of total genomic DNA with endonucleases that cleave infrequently. The patterns generated by PFGE are commonly used to identify clinical pathogens (8), to construct physical genomic maps (23), and to differentiate closely related species, serovars, and pathovars of bacteria (17). For example, this technique has been used to follow the spread of particular strains of E. amylovora through Europe and the Mediterranean region (31,32, S. Jock, W.-S. Kim, V. Donat, M. M. Lopez, C. Bazzi, and K. Geider, unpublished data).

In this study, we tested several fast, sensitive, species-specific PCR assays for the detection and identification of P. stewartii. Primers were designed to amplify the $16 \mathrm{~S}$ rRNA intergenic transcribed spacer (ITS) region and two pathogenicity-related genes, $\operatorname{hrpS}$ and $c p s D$. These assays were evaluated with known strains, typical "false positive" bacteria isolated from corn leaf lesions, and plant material. In addition, we demonstrated the use of PFGE to confirm the identification of $P$. stewartii and to differentiate strains for epidemiological studies.

\section{MATERIAL AND METHODS}

Bacterial strains. Reference strains and their sources are listed in Table 1. In addition, E. mallotivora CFBP2503, E. (syn. Brenneria) quercina CFBP3617, E. (syn. Brenneria) rubrifaciens CFBP3619, E. psidii CFBP3627, E. (syn. Pectobacterium) cacticida CFBP3628, E. (syn. Brenneria) salicis CFBP802, E. tracheiphila CFBP2355, E. (syn. Pectobacterium) 
cypripedii CFBP3613, E. persicinus CFBP3622, E. rhapontici CFBP3618, E. nigrifluens CFBP3616, and E. amylovora CFBP1232 were obtained from the Collection Française des Bactéries Phytopathogènes, INRA, Angers, France (Table 2). The identification of all Pantoea strains was confirmed and pathogenicity on sweet corn was retested as described below. Strains DC129 and DC130 were received as unidentified isolates from S. Walker (University of Missouri) and later classified as Pantoea ananas. Bacteria isolated from Ohio corn leaves collected from 1995 to 1998 were given DC400 strain designations and classified as listed in Table 3 .

Isolation and identification of bacteria isolated from maize leaves. Bacteria were isolated from triturated lesions excised from corn leaves collected in fields in Ohio (Table 3) by plating on casamino acidspeptone-glucose (CPG) agar and phenotypically identified as described in Coplin and Kado (12). Initial identification was based on the gram reaction ( $\mathrm{KOH}$ test); Hugh-Liefson test; pigment production; sensitivity to stewartan-dependent phage $\Phi K 9$ (3); hypersensitive reaction (HR) on tobacco; motility; acid from glycerol, melibiose, meso-inositol, and sorbitol; and utilization of malonate. Identifications were confirmed by gas chromatographicfatty acid methyl ester (GC-FAME) analysis with a model HP6890 Microbial Identification System equipped with version 3.9 of the Microbial Identification Aerobic Library (Microbial Identification, Inc., Newark, DE.). Strains were identified to the species and genus levels according to manufacturer's specifications. Strains with similarity indices $\geq 0.3$ but lacking the required 0.1 degree of separation between generic classifications were identified as cluster groups. Strains with similarity indices $<0.3$ or with identifications of "no match" were considered unclassified. In addition, pathogenicity on sweet corn seedlings was tested as described below.

PCR assay. The primers CPSL1 (CCTGTCAGTCTCGAACC) and CPSR2c (ATCTCGAACCGGTAACC), were designed from the sequence of the $c p s D$-region (14), which encodes synthesis of capsular polysaccharide stewartan and appears to be unique for P. stewartii (D. L. Coplin and D. R. Majerczak, unpublished). Primers HRP1d (GCACTCATTCCGACCAC) and HRP3c (GCGGCATACCTAACTCC) are internal to the $h r p S$ open reading frame (ORF; 20; Genbank AF282857). Primers from the 16S-23S rRNA/ITS region (EMBL AJ311838) were ES16 (GCGAACTTGGCAGAGAT, 993 nt in 16S rRNA); ESIG1 (ESR1) (CGAAGC-GAGGACACACG, 71 nt in the ITS region); and ESIG2c (GCGCTTGCGTGT-TATGAG, $361 \mathrm{nt}$ the complementary strand of the ITS region). These positions correspond to nucleotides 993, 1605, and 1895, respectively, in EMBL accession AJ311838.

Whole bacteria were used for a PCR assay that was carried out in a volume of 50 $\mu \mathrm{l}$ with $25 \mathrm{pmol}$ of each primer and $0.5 \mathrm{U}$ of Tth polymerase (Amersham Pharmacia Biotech Europe, Freiburg, Germany) as described previously $(1,2)$. Denaturation was done at $94^{\circ} \mathrm{C}$ (one cycle for $1 \mathrm{~min}$ and subsequent cycles for $15 \mathrm{~s}$ ); the annealing of primer to the template DNA was for 15 $\mathrm{s}$ at 52 to $55^{\circ} \mathrm{C}$ in the case of the CPS and HRP primers or 55 to $58^{\circ} \mathrm{C}$ in the case of the ITS primers; and polymerization was at $72^{\circ} \mathrm{C}$ for $30 \mathrm{~s}$. After 25 cycles $(1.5$ to $2 \mathrm{~h}$ ), the PCR product was separated on a $1 \%$ agarose gel $(1.5$ to $2 \mathrm{~h}$ at $1.5 \mathrm{~V} / \mathrm{cm})$, stained with ethidium bromide, and photographed under UV light.

Table 1. Bacterial reference strains used for polymerase chain reaction assays and pulsed field gel electrophoresis analyses

\begin{tabular}{|c|c|c|c|}
\hline Strain & Host & Origin & Source (alternate no.) \\
\hline \multicolumn{4}{|l|}{ Pantoea stewartii subsp. stewartii (syn. Erwinia stewartii) } \\
\hline SS102 & Zea mays & New York & $16(\mathrm{Z} 05)$ \\
\hline SS104 & Z. mays & Illinois, 1967 & $\mathrm{ICPPB}^{\mathrm{a}}$ \\
\hline SW1, SW2 & Z. mays, & Ohio, 1974 & D. Coplin \\
\hline SW4, SW18, SW24, SW25, SW28, SW31, SW32 & Z. mays & Ohio, 1975 & D. Coplin \\
\hline SW5, SW19 to SW23, SW26 & Z. mays & Kentucky, 1975 & D. Coplin \\
\hline SW11 & Z. mays & Illinois, 1975 & D. Coplin \\
\hline SW13 & Z. mays & Indiana, 1975 & D. Coplin \\
\hline DC117, DC119 & Z. mays & Missouri, 1976 & S. Walker \\
\hline DC116, DC122, DC133 & Z. mays & Missouri, 1976, avirulent & S. Walker \\
\hline DC145 & Chaetocnema pulicaria & Connecticut, 1976 & D. Sands (ATCC29227) \\
\hline DC146 & C. pulicaria & Connecticut, 1976 & D. Sands (ATCC29228) \\
\hline DC147 & C. pulicaria & Connecticut, 1976 & D. Sands (ATCC29229) \\
\hline DC162 & Z. mays & New York, 1975 & T. Woods (Es-5) \\
\hline DC172 & Z. mays & Iowa, 1940, avirulent & Lindstrom (SS11), ICPPB \\
\hline DC283 & Z. mays & $\mathrm{Nal}^{\mathrm{r}}$ mutant of SS104 & 15 \\
\hline \multicolumn{4}{|l|}{ P. ananas } \\
\hline CU2093 & Ananas comosus & Hawaii & A. Alvarez (M189) \\
\hline DC129, DC130 & Z. mays & Missouri, 1976 & S. Walker \\
\hline DC532 & $\ldots$ & $\ldots$ & S. Lindow (Cit 30-11) \\
\hline P. agglomerans pv. gypsophilia DC556 & Gypsophila paniculata & Israel & I. Barash \\
\hline \multicolumn{4}{|l|}{ P. agglomerans pv. herbicola } \\
\hline C9-1 & Malus. sylvestris & United States & C. Ishimaru \\
\hline Eh358-6A & Prunus domestica & Switzerland, 1975 & 18 \\
\hline Eh7/95 & Z. mays & Germany, 1995 & \\
\hline Eh8/96 & Z. mays & Germany, 1996 & \\
\hline EhA1-81 & Cotoneaster salicifolius & Switzerland, 1981 & 18 \\
\hline EhA1-82 & C. salicifolius & Germany, 1982 & 18 \\
\hline EhNZ & Pyrus communis fruits & New Zealand & 2 \\
\hline EhSB & P. communis & Germany & 18 \\
\hline EhY112-9 & M. sylvestris & United States, 1986 & 18 \\
\hline P. agglomerans subsp. synvitivora Ehs 2035 & $\ldots$ & England, 1984 & 18 \\
\hline Pantoea spp.DC131, DC136 & Z. mays & Missouri, 1976 & S. Walker \\
\hline \multicolumn{4}{|l|}{ Erwinia amylovora } \\
\hline Ea179 & Cotoneaster sp. & Germany, 1979 & 18 \\
\hline E9 & M. sylvestris & USA & 18 \\
\hline E. carotovora subsp. carotovora Ecc 499 & $\ldots$ & Germany, 1986 & 18 \\
\hline E. carotovora subsp. atroseptica Eca 185 & $\ldots$ & Germany, 1986 & 18 \\
\hline Pseudomonas syringae pv. syringae $4 \mathrm{U}$ & P. communis & Germany, 1991 & W. Zeller \\
\hline Xanthomonas campestris pv. campestris XCC356 & $\ldots$ & Germany & M. Nachtigall \\
\hline
\end{tabular}

${ }^{\mathrm{a}} \mathrm{ICPPB}=$ International Collection of Plant Pathogenic Bacteria, Davis CA, no longer available. 
Pathogenicity tests on corn seedlings. Sweet corn seedlings (cv. Earliking or Seneca Horizon) were grown at $28^{\circ} \mathrm{C}$ and $16 \mathrm{~h}$ daylight in flats ( 20 by 10 by $2.5 \mathrm{in}$.) containing soil:vermiculite:peat moss (1:1:1). In order to assay the virulence of $P$. stewartii strains, 8-day-old seedlings were inoculated using two different inoculation procedures. In the "cut stump" method, $5.0 \mu \mathrm{l}$ of inoculum $(1,250 \mathrm{CFU} /$ plant $)$ were pipetted onto the cut ends of decapitated 8-day-old seedlings; the plants were rated at 10 days after inoculation. For the "whorl" inoculation method, $200 \mu \mathrm{l}$ of inoculum $\left(10^{7} \mathrm{CFU} / \mathrm{ml}\right)$ in 0.01 $\mathrm{M}$ potassium phosphate buffer $(\mathrm{pH} 7.0)$ containing $0.2 \%$ Tween 40 was placed in the whorls of the seedlings; the plants were rated at 10 days after inoculation as described in Table 3.

Preparation of plant material for PCR. One-week-old seedlings of susceptible sweet corn were inoculated by the cut stump or whorl methods. After 1 week, 10 $\mathrm{mg}$ of material from leaves with symptoms or healthy control leaves were cut and slices were placed into an Eppendorf tube containing $100 \mu \mathrm{l}$ of sterile water. After removing the debris by centrifugation, the suspension was serially diluted and used for the PCR assays as above.

PFGE assay. The PFGE analysis of chromosomal DNA of $P$. stewartii was performed as described by Zhang and Geider (31). Similarity coefficients were calculated from the restriction fragments on the gels according to Nei and Li (27).

\section{RESULTS}

Identification of $P$. stewartii by PCR with primers from the rRNA ITS region. The chromosomal ITS regions encoding the rRNA vary considerably between related bacterial species (21). By comparing the corresponding sequences of the ITS regions from $P$. stewartii (EMBL AJ311838), E. amylovora (EMBL AJ010485), Escherichia coli (Genbank J01695), and Erwinia pyrifoliae (EMBL AJ009930) (Fig. 1A), two primers (ESIG1/ESIG2c) were selected, which appeared to be highly specific for $P$. stewartii. They amplified a 0.29-kb DNA fragment. In order to obtain a larger fragment for easier detection on gels, a second forward primer (ES16) was selected from within the 16S rRNA gene. The ES1G2c/ES16 primers amplified a $0.92-\mathrm{kb}$ fragment. Both primer pairs, ESIG1/ESIG2c and ES16/ESIG2c, were tested with 33 known strains of $P$. stewartii, 12 strains of other Pantoea spp., 14 related Erwinia spp., and one strain of Xanthomonas campestris pv. campestris (Table 2). All P. stewartii strains yielded the expected amplicons. Only one $P$. ananas strain produced bands with the ES16/IG2 primers and another produced faint bands with both primer sets. Other Pantoea and Erwinia strains did not produce these PCR products, including the type strains of many present and former Erwinia spp. and other plant-associated bacteria (Fig. 2).

Use of the ITS/16S rRNA PCR assay with bacteria isolated from old field samples. $P$. stewartii is easily isolated from fresh lesions on corn leaves and can be tentatively identified by colony type, odor, and motility and then confirmed with a pathogenicity test (12) or agarose gel electrophoresis of plasmids (15). However, after plant material has been in storage, saprophytic bacteria multiply and P. stewartii is harder to recover because it is a poor competitor and cannot easily survive desiccation. The bacteria most frequently isolated are related yellow-pigmented pantoeas, such as $P$. agglomerans $\mathrm{pv}$. herbicola or $P$. ananas. To test the validity of our PCR assays using ITS primers, we isolated a number of bacteria from old corn leaves that resembled $P$. stewartii on CPG plates. Corn leaves were collected during the summers of 1995, 1996, and 1998 and held in storage in brown paper bags at $4^{\circ} \mathrm{C}$ until spring 1999, when we attempted to identify the pathogen among colonies isolated from these leaves on CPG agar. Twenty-seven samples were taken from 24 fields at 13 locations representing seven counties in Ohio. In all, 29 bacterial isolates were characterized by pathogenicity, biochemical traits, and PCR with the ITS primers (Table 3). Seven samples yielded $P$. stewartii and these strains gave the expected amplicons with both primer sets and were sensitive to phage $\Phi \mathrm{K} 9$, nonmotile, and virulent on sweet corn. The most frequent species was a group of 11 strains that are probably $P$. ananas. Of this group only three gave faint and variable signals with the ITS primer sets. These

Table 2. Polymerase chain reaction (PCR) assays with reference strains of Pantoea stewartii subsp. stewartii and other bacteria ${ }^{\mathrm{a}}$

\begin{tabular}{|c|c|c|c|c|}
\hline Strain & $\begin{array}{c}\text { IG1/IG2c } \\
(0.29 \text { kb })\end{array}$ & $\begin{array}{c}\text { ES16/IG2 } \\
(0.92 \text { kb) } \\
\end{array}$ & $\begin{array}{c}\text { HRP } \\
(0.9 \text { kb) }\end{array}$ & $\begin{array}{c}\text { CPS } \\
(1.1 \mathrm{~kb}) \\
\end{array}$ \\
\hline \multicolumn{5}{|l|}{ Pantoea spp. } \\
\hline \multicolumn{5}{|l|}{ P. stewartii subsp. stewartii } \\
\hline DC117, DC145, DC172, DC283, SW2, SW4, SW5, SW11, SW19, SS104 & + & + & + & + \\
\hline SW1, SW13, SW18, SW21, SW22, SW23, SW24, SW25, SW26, SW28, & & & & \\
\hline SW31, SW32, SS102, SS104, DC119, DC146 & + & + & nd & nd \\
\hline DC145 & + & \pm & nd & nd \\
\hline \multicolumn{5}{|l|}{ P. stewartii subsp. stewartii, avirulent strains } \\
\hline DC122, SW20, DC133, DC147, DC162 & + & + & + & + \\
\hline DC116 & + & + & - & - \\
\hline \multicolumn{5}{|l|}{ P. ananas } \\
\hline CU2093, DC532 & - & - & - & _- \\
\hline DC129 & - & $\mathrm{v}$ & - & - \\
\hline DC130 & $\mathrm{v}$ & + & nd & nd \\
\hline P. ananas pv. uredovora GSPB $457^{\mathrm{b}}$ & - & - & nd & - \\
\hline \multicolumn{5}{|l|}{ P. agglomerans pv. herbicola } \\
\hline Eh7/95 & - & - & - & + \\
\hline Eh C9-1 & - & $\mathrm{v}$ & - & - \\
\hline Eh8/96, EhA1-81, EhNZ, EhSB & _- & - & - & - \\
\hline P. agglomerans pv. gypsophilae DC556 & - & - & - & - \\
\hline P. agglomerans subsp. synvitivora Ehs 2035 & _- & - & - & - \\
\hline Erwinia amylovora Ea1/79, E9 & - & - & - & - \\
\hline Erwinia type strains $\mathrm{c}^{\mathrm{s}}$ & _- & _ & _- & _- \\
\hline Other bacteria ${ }^{\mathrm{d}}$ & - & - & - & - \\
\hline
\end{tabular}

${ }^{\mathrm{a}} \mathrm{nd}=$ not done; $\mathrm{v}=\mathrm{PCR}$ reaction giving variable intensity of bands (0 to $30 \%$ of normal).

${ }^{\mathrm{b}}$ GSPB = Göttinger Sammlung Phytopathogener Bakterien, Göttingen, Germany.

${ }^{\mathrm{c}} \mathrm{CFBP}=$ Collection Française des Bactéries Phytopathogènes, INRA, Angers, France: E. mallotivora CFBP2503, E. quercina CFBP3617, E. rubrifaciens CFBP3619, E. psidii CFBP3627, E. cacticida CFBP3628, E. salicis CFBP802, E. tracheiphila CFBP2355, E. cypripedii CFBP3613, E. persicinus CFBP3622, E. rhapontici CFBP3618, E. nigrifluens CFBP3616, and E. amylovora CFBP1232

${ }^{\mathrm{d}}$ Xanthomonas campestris pv. campestris XCC356, E. amylovora Ea1/79, E. carotovora. subsp. atroseptica Eca185, and E. carotovora subsp. carotovora Ecc499 
strains were gram negative, motile, facultatively anaerobic, reacted with phage $\Phi K 9$, and elicited the HR on tobacco. Three strains produced a few water-soaked lesions but did not cause wilting of sweet corn seedlings. They were reisolated from the infected plants and apparently were the cause of the lesions. In tests to differentiate $P$. agglomerans and $P$. ananas, all 11 Pantoea strains shared similar biochemical characteristics; they produced acid from glycerol, melibiose, meso-inositol, and sorbitol, and they were unable to use malonate. GC-FAME analysis of four representative strains from this group indicated they were $P$. ananas. The remaining 11 strains were a heterogeneous group of yellow-pigmented, $\mathrm{HR}^{-}$, gramnegative, and gram-positive bacteria. None of them reacted with the ITS primer sets or were sensitive to phage $\Phi K 9$, but several displayed delayed lesion formation on sweet corn seedlings. Five were aerobes and the rest were facultative anaerobes. GC-FAME was only able to identify one strain as $P$. agglomerans and another as Pseudomonas aureofaciens.

Identification of Pantoea stewartii by PCR with primers from $h r p S$. Two 17-mer primers, HRP1d and HRP3r, were designed to amplify a $0.90-\mathrm{kb}$ fragment from the hrpS ORF (bp +21 to +910; Genbank AF282857). The nucleotide sequences were chosen from a region of $h r p S$ that is significantly different in the E. amylovora (Genbank AF083877) and $P$. agglomerans pv. gypsophilae (Genbank AF272053) hrpS homologs (Fig. 1B).

We tested the HRP primers against 16 known strains of $P$. stewartii from different geographic regions in the United States, 25 strains of other Erwinia and Pantoea spp., and 1 strain of $X$. campestris pv. campestris (Table 2). All of the P. stewartii strains tested positive for the 0.90-kb hrpS amplicon (Fig. 3), except for one avirulent strain, DC116. None of the strains of $P$. agglomerans, $P$. ananas, Erwinia spp., or $X$. campestris pv. campestris produced a specific product even when a high concentration of cells was used ( $\left.5 \times 10^{5} \mathrm{CFU} / \mathrm{assay}\right)$, except for $P$. agglomerans pv. herbicola Eh7/95. To detect $P$. stewartii by PCR with the HRP primers, the minimal concentration of bacterial cells needed to obtain a visible amplification product was $20 \mathrm{CFU}$.
Identification of $P$. stewartii by PCR with primers from the cps region. To detect the corn pathogen $P$. stewartii by an additional PCR assay, a pair of primers was designed from the $c p s D$ and $c p s E$ genes, which encode glycosyltransferases for the biosynthesis of stewartan (14). One of the three genes that differ between the $P$. stewartii and E. amylovora EPS gene clusters is $c p s D$, and it appears to be unique to $P$. stewartii. Primer CPSL1 is located in the end of $c p s D$ and primer CPSR2c located in the middle of cpsE; together they amplified a 1.1-kb DNA fragment.

$P$. stewartii cells were used directly in PCR assays (Table 2). Of 16 known strains of $P$. stewartii isolated from different regions, 15 gave the expected $1.1-\mathrm{kb}$ amplicon. Only DC116, which is nonmucoid and avirulent, was negative. The minimal con-

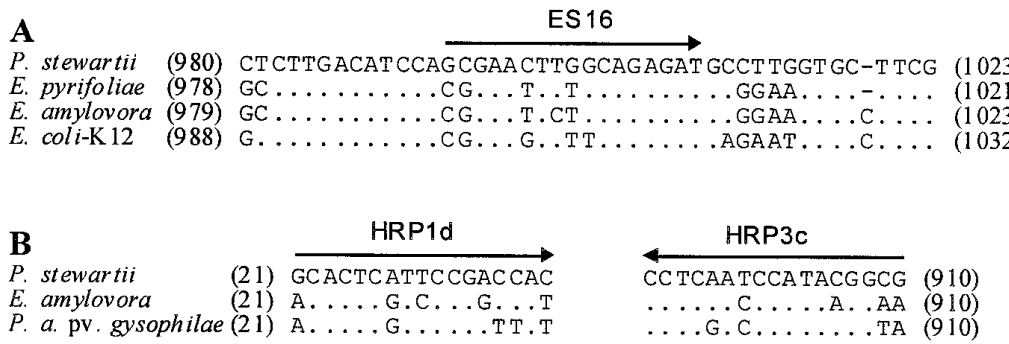

Fig. 1. Partial nucleotide sequences of $\mathbf{A}$, the $16 \mathrm{~S}$ rRNA and $\mathbf{B}$, the hrpS regions of Pantoea stewartii and other bacteria used for selection of polymerase chain reaction primers. Alignments were done with the sequences of $P$. stewartii DC283, Erwinia amylovora Ea1/79, Escherichia coli K-12, Erwinia pyrifoliae Ep1/96, and P. agglomerans pv. gypsophilae (accession numbers given in the text). Primers ES16, HRP1d, and HRP3c are indicated by arrows.

Table 3. Analysis of yellow isolates from corn by polymerase chain reaction (PCR), plant assays, and phage typing for identification of Pantoea stewartii subsp. stewartii

\begin{tabular}{|c|c|c|c|c|}
\hline \multirow[b]{2}{*}{ Strain } & \multirow[b]{2}{*}{ Path $^{\mathbf{b}}$} & \multirow[b]{2}{*}{$\mathbf{H R}^{\mathbf{c}}$} & \multicolumn{2}{|c|}{ PCR primers/amplicon ${ }^{\mathrm{a}}$} \\
\hline & & & IG1/2 (0.29 kb) & 16S/IG (0.92 kb) \\
\hline \multicolumn{5}{|l|}{ P. stewartii subsp. stewartii } \\
\hline DC422, DC424, DC436, DC438, DC440, DC441, DC442 & 3 & + & + & + \\
\hline \multicolumn{5}{|l|}{ P. ananas } \\
\hline DC131, DC136 ${ }^{\mathrm{d}}$ & nd & + & - & - \\
\hline DC415 & 0.7 & + & - & - \\
\hline DC416, DC421, DC423, DC426, DC435 & 0 & + & - & - \\
\hline DC417 & 0.2 & + & $\mathrm{v}$ & $\mathrm{v}$ \\
\hline DC418 & 0 & + & $\mathrm{v}$ & $\mathrm{v}$ \\
\hline DC427 & 0 & + & - & $\mathrm{v}$ \\
\hline DC430 & 0 & + & $\mathrm{v}$ & - \\
\hline DC434 & 1.0 & + & - & - \\
\hline P. agglomerans pv. herbicola DC432 & 1.1 & - & - & - \\
\hline Pseudomonas aureofaciens DC420 & 0.7 & - & $\mathrm{v}$ & - \\
\hline \multicolumn{5}{|l|}{ Unidentified, aerobic, gram negative } \\
\hline DC419, DC425, DC431 & 0 & - & - & - \\
\hline DC428 & 0.4 & - & $\mathrm{v}$ & - \\
\hline Unidentified, facultative anaerobic, gram negative DC439 & 0 & - & - & - \\
\hline Curtobacterium spp.DC433 & 0.6 & - & - & - \\
\hline \multicolumn{5}{|l|}{ Unidentified, facultative anaerobic, gram positive } \\
\hline DC429 & 0.4 & - & - & - \\
\hline $\mathrm{DC} 444^{\mathrm{e}}$ & $0.1^{\mathrm{f}}$ & - & - & - \\
\hline $\mathrm{DC} 443^{\mathrm{e}}$ & $2.2^{\mathrm{f}}$ & - & - & - \\
\hline
\end{tabular}


centration of bacterial cells needed to obtain a visible PCR fragment was 20 CFU/assay. All other plant-associated $E r$ winia and Pantoea spp. listed in Table 2 (27 strains), as well as $X$. campestris pv. campestris XCC356 and Pseudomonas syringae pv. syringae $4 \mathrm{U}$, either did not give the 1.1-kb amplicon or else occasionally gave nonspecific DNA bands of a different size when high amounts of
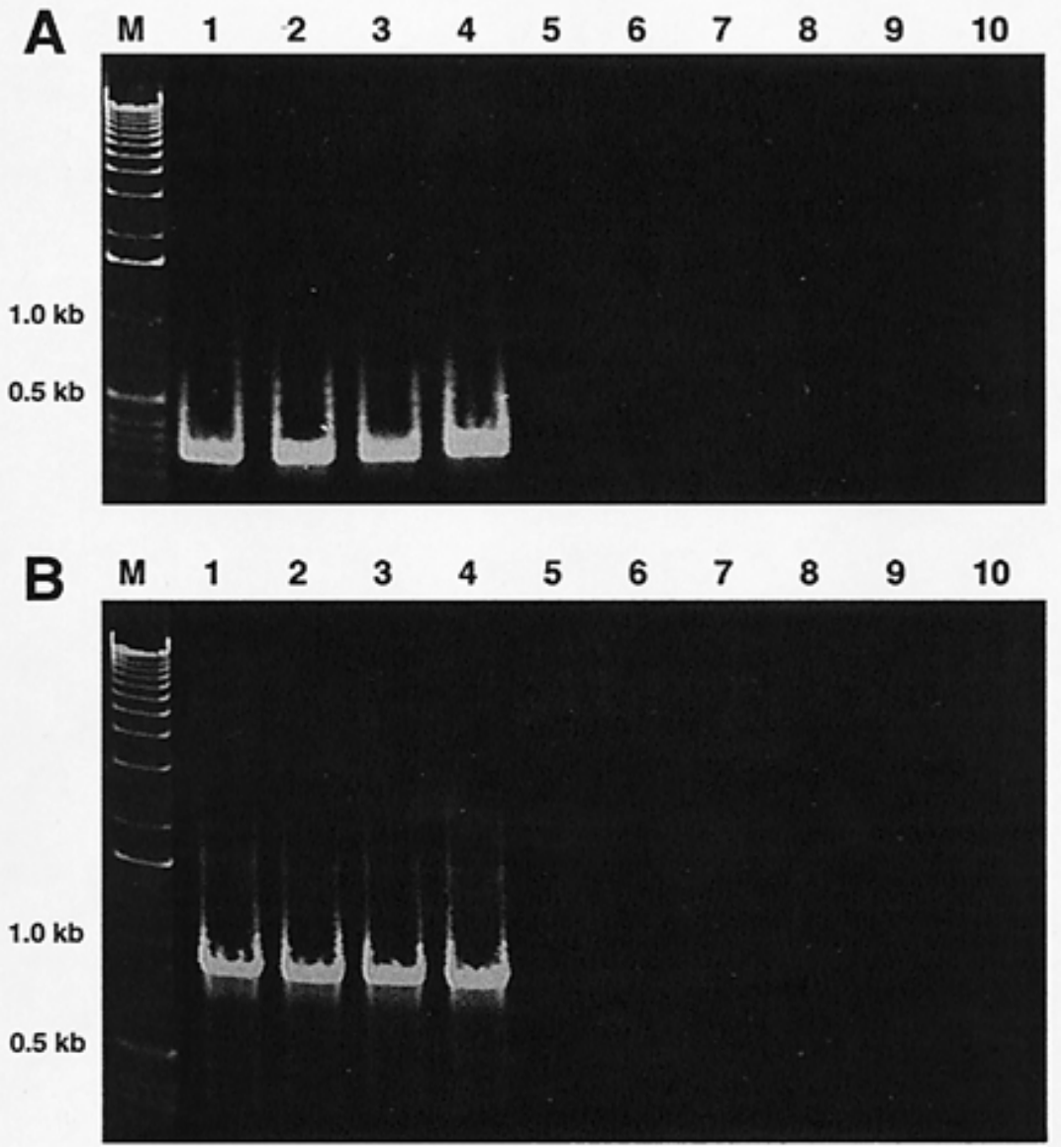

Fig. 2. Amplification of the $16 \mathrm{~S} / 23 \mathrm{~S}$ rRNA spacer region using primers designed to detect Pantoea stewartii. Products have been separated by agarose gel electrophoresis. A, ESIG1/ESIG2c primers $(0.29 \mathrm{~kb})$ and B, ES16/ESIG2c primers $(0.92 \mathrm{~kb})$. Lanes 1 to 4, P. stewartii DC283, SW2, SS104, and DC117, respectively; lanes 5 to 9, P. agglomerans pv. herbicola EhA1-81, EhY112-9, EhA1-82, Eh7/95, and Eh8/96, respectively; lane 10, water control; and lane M, 1-kb ladder marker DNA (Life Technologies GIBCO BRL, Gaithersburg, MD).

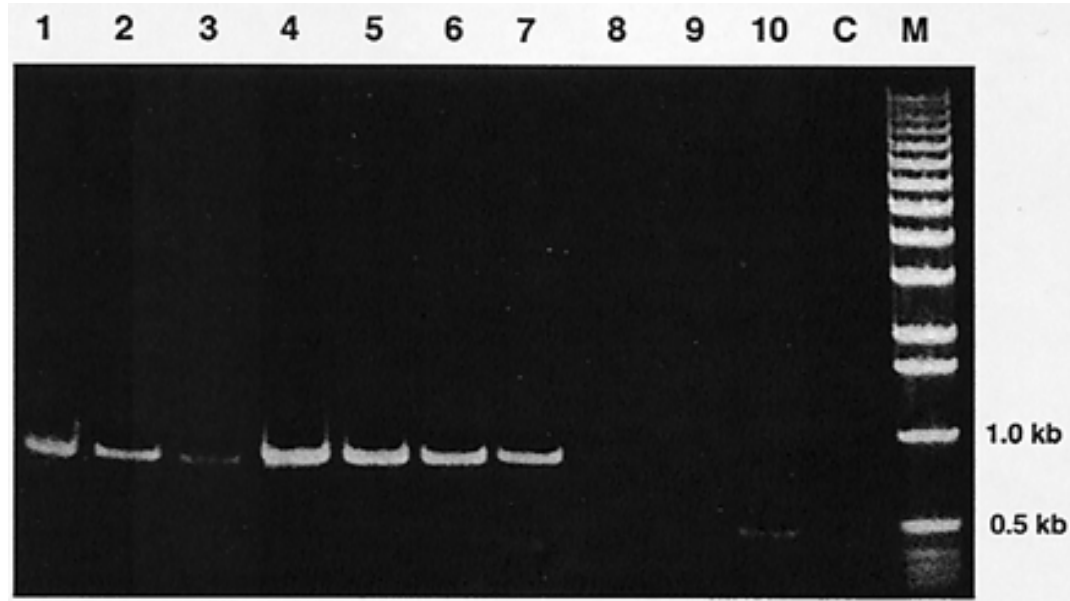

Fig. 3. Amplification of the hrpS gene using primers HRP1d and HRP3r, designed to detect Pantoea stewartii. Products have been separated by agarose gel electrophoresis. Lanes 1 to $7, P$. stewartii strains SW2, SW4, SW5, SW19, DC283, SS104, and DC117, respectively; lanes 8 to 10, $P$. agglomerans pv. herbicola strains Eh7/95, Eh8/96, and EhNZ, respectively; lane C, water control; and lane M, 1-kb ladder marker DNA (Life Technologies GIBCO BRL, Gaithersburg, MD).

cells ( $>10^{5}$ cells/assay) were used. Pantoea agglomerans pv. herbicola Eh7/95 gave an amplification product of approximately 1.1 $\mathrm{kb}$, although this strain was negative with the other primers designed to identify $P$. stewartii.

Use of the PCR assays with mixed cultures and plant material. To simulate mixed bacterial cultures that might be obtained when isolating from plants, $P$. stewartii cells $\left(5 \times 10^{2}\right.$ CFU/assay) were mixed with either Pseudomonas syringae pv. syringae $4 \mathrm{U}, X$. campestris pv. campestris XCC356, E. carotovora subsp. atroseptica Eca185, Pantoea agglomerans pv. herbicola EhNZ, or E. amylovora E9 cells $\left(1 \times 10^{6} \mathrm{CFU} /\right.$ assay $)$ and the mixtures were used in PCR assays with the CPS primers. In all cases, the $1.1-\mathrm{kb}$ amplicon was detected when $P$. stewartii cells were added, but it was not present in the controls (Fig. 4).

Leaves from healthy and inoculated sweet corn also were assayed for the presence of $P$. stewartii. The tissue suspensions from lesions on infected plants gave the correct amplicon with all four PCR primer pairs, whereas tissue from healthy plants tested negative. The specific amplicon could be visualized even when the aqueous suspension of infected leaf tissue was diluted as much as 1,000-fold. Plating showed that the minimum number of $P$. stewartii cells needed for detection from leaf tissue was 200 CFU.

PFGE assays of $P$. stewartii strains and a comparison with other Erwinia and Pantoea spp. Erwinia and Pantoea spp. have a high GC content (50 to 58\%); therefore, we chose the restriction endonu-

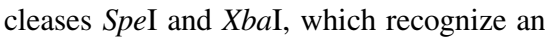
AT-rich hexanucleotide sequence, to produce genomic DNA restriction fragments. The $X b a \mathrm{I}$ restriction digest gave rise to fewer fragments than the SpeI digest. Eight strains of $P$. stewartii were examined and these yielded at least $12 \mathrm{XbaI}$ bands in the range of 100 to $800 \mathrm{~kb}$ (Fig. 5A). Common XbaI fragments of $375,320,270,235,210$, and $135 \mathrm{~kb}$ were shared by all strains. $P$. stewartii strains were easily distinguished from other Erwinia and Pantoea spp. by their PFGE fingerprints. A large, 150-kb plasmid was also observed in the PFGE analysis of undigested chromosomal DNA of DC283. This confirmed the result obtained by Coplin et al. (15) that P. stewartii possesses large plasmids.

In an SpeI digest, $P$. stewartii strains, isolated from different geographic origins at different times, had divergent restriction patterns, except for SW19 and DC145 (Fig. 5B), which also had an identical pattern in XbaI digests. These two strains were isolated from different states, 1 year apart. However, the patterns of the nalidixic acid-resistant strain DC283 and its reported parent strain SS104 also were different, suggesting that genetic rearrangements occurred after 24 years in cul- 
ture. Three common bands of 145, 230, and $325 \mathrm{~kb}$ could be observed among more than 20 fragments from the eight strains. The similarity coefficient among the strains ranged from 60 to $100 \%$ based on the PFGE patterns. The $P$. agglomerans pv. herbicola strains Eh7/95 and Eh8/96 from corn leaves in Germany showed completely different $\mathrm{Xba \textrm {I }}$ and SpeI patterns when compared with $P$. stewartii strains and clearly did not belong to this species. Comparison of the PFGE patterns of $P$. stewartii strains with patterns obtained with other species, such as $P$. agglomerans, $P$. ananas, or E. carotovora, also revealed distinct patterns after $X b a \mathrm{I}$ digestion of genomic DNA and subsequent PFGE analysis (data not shown). These data

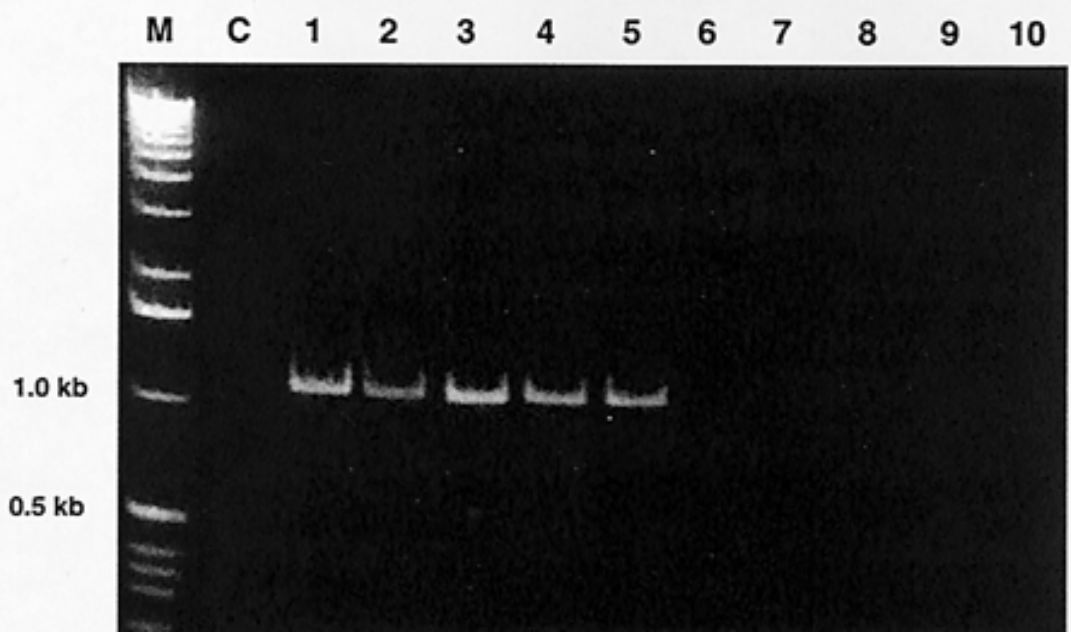

Fig. 4. Amplification of the Pantoea stewartii cpsD-E region using primers CPSL1 and CPSR2c in the presence of other plant-associated bacteria. Products have been separated by agarose gel electrophoresis. P. stewartii was added at $500 \mathrm{CFU} / \mathrm{assay}$; the other bacteria at $10^{6} \mathrm{CFU} /$ assay. Lane 1, P. stewartii DC283 with Pseudomonas syringae 4U; lane 2, DC283 with Xanthomonas campestris pv. campestris XCC356; lane 3, DC283 with Erwinia carotovora subsp. atroseptica Eca185; lane 4, DC283 with Pantoea agglomerans pv. herbicola EhNZ; lane 5, DC283 with E. amylovora E9; lanes 6 to 10 without addition of P. stewartii; 4U, XCC356, Eca185, EhNZ, and E9, respectively; lane C, water control; and lane M, 1-kb ladder (Life Technologies GIBCO BRL, Gaithersburg, MD).

suggest that PFGE analysis is not only useful for differentiation of $P$. stewartii strains, but is also very useful to confirm species identification.

\section{DISCUSSION}

In most instances, the symptoms of Stewart's wilt are very distinct and lesions are associated with flea beetle feeding scars. This makes routine diagnosis of this disease in the field rather simple, when followed by the microscopic observation of ooze in the laboratory. However, Stewart's wilt can be confused with Goss' wilt, caused by Clavibacter michiganensis subsp. nebraskensis and, to complicate matters, some normally saprophytic bacteria, such as $P$. ananas, can cause watersoaked lesions in greenhouse tests. This means that casual diagnosis of Stewart's wilt is not sufficient to meet plant quarantine requirements. It is recommended that (i) quarantine countries survey regularly for Stewart's wilt, (ii) seed production fields be inspected for systemic infection by $P$. stewartii, and (iii) seed from infested fields be tested by ELISA. Currently, an ELISA test (22) is the only accepted means of detection of $P$. stewartii in seed, because PCR assays have not been sufficiently developed and tested. Commercial ELISA kits represent a significant expense in terms of materials and time; therefore, there is a need for a one-step, highly specific PCR assay for P. stewartii. PCR assays, such as those we have developed in this study, should be valuable for seed
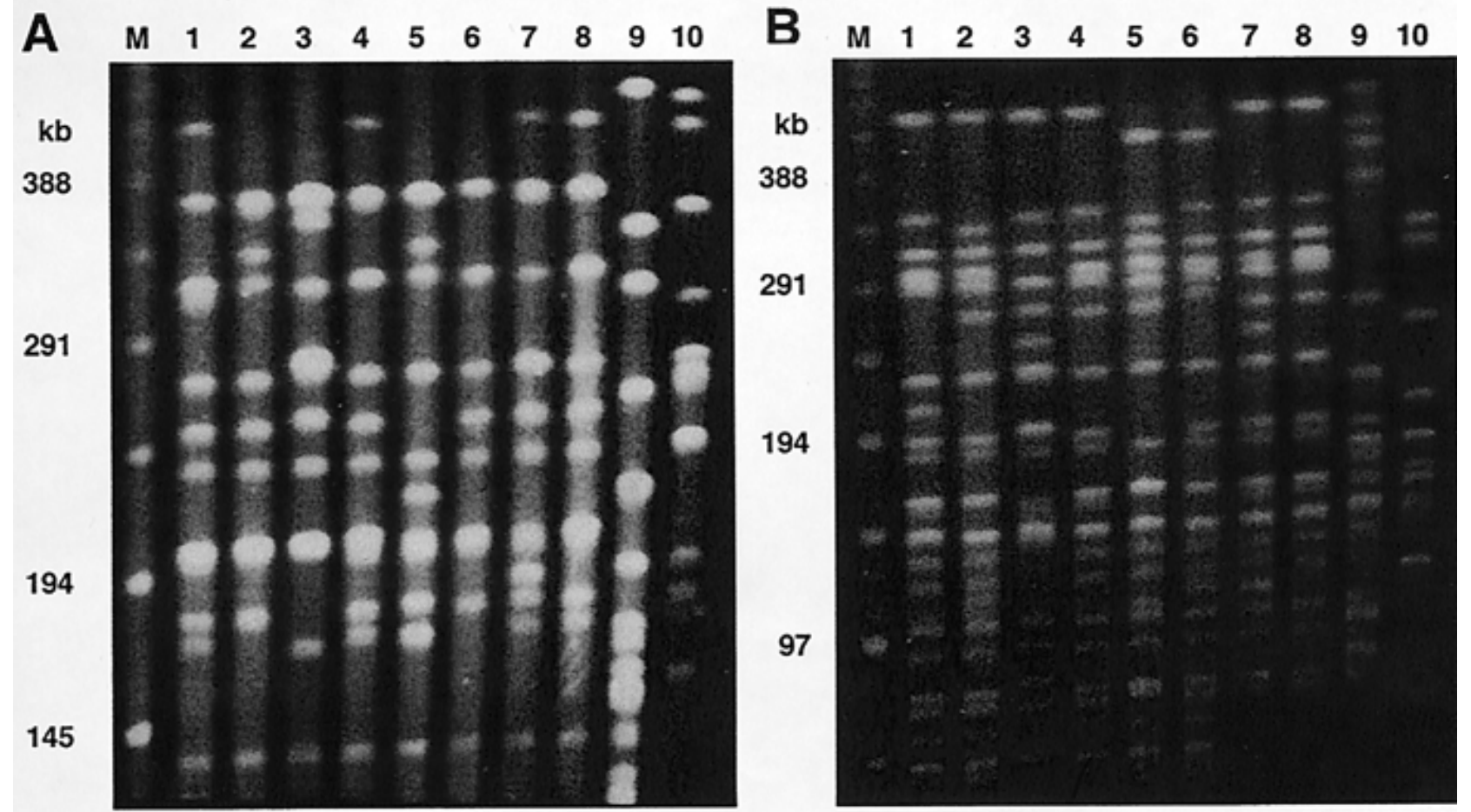

Fig. 5. Separation of fragments from A, XbaI- and B, SpeI-digested chromosomal DNA of Pantoea stewartii strains and other plant-associated bacteria by pulsed field gel electrophoresis. Lanes 1 to 8, P. stewartii strains SW2, SW4, SW5, SW19, DC283, SS104, DC117, and DC145, respectively; lanes 9 to 10, P. agglomerans pv. herbicola Eh7/95 and Eh8/96, respectively; lane M, ladder of phage $\lambda$ oligomers (New England Biolabs, Beverly MA). Linear ramping times were from 5 to $25 \mathrm{~s}$ over $22 \mathrm{~h}$ and from 1 to $40 \mathrm{~s}$ over $18 \mathrm{~h}$ at $5 \mathrm{~V} / \mathrm{cm}$. 
certification tests, to confirm field and clinic diagnoses, and in epidemiological studies involving both seed and insect vectors.

Preliminary identification of suspected $P$. stewartii isolates from corn plants can be done by pigmentation, gram reaction (KOH test), motility, and oxidation/ fermentation tests, followed by a pathogenicity test. However, for quicker and more certain confirmation of species identification, one must resort to metabolic profiling (29), FAME, plasmid profiles (15), 16S rDNA sequencing, or other systems for bacterial identification. The PFGE fingerprinting technique presented in this study is a reliable, but sumptuous, test for confirming the identity of $P$. stewartii isolates. PCR is a fast, specific, and sensitive method and many plant pathology labs are now equipped for it; therefore, this type of assay is greatly needed. The one-step PCR assays reported here are quicker and cheaper to perform than the LCR and nested PCR assays previously reported $(4,30)$ and appear to be just as specific and sensitive. One-step PCR assays also will accelerate detection time and minimize the risk of contamination, which is increased in nested PCR.

In this study, several sets of PCR primers were tested for the detection and identification of $P$. stewartii from mixed and pure cultures of bacteria, as well as plant material. These tests were based on sequences from two EPS genes, an hrp gene, and the 16S rRNA ITS region. All of the primers worked well in distinguishing $P$. stewartii from a large collection of related yellow bacteria that are commonly isolated from corn leaves and from strains representing 17 species from the former Erwinia group. With one exception, they detected avirulent as well as virulent $P$. stewartii strains. P. stewartii strain DC116, which was identified by biochemical tests and GC-FAME, reacted with the ITS primers but not the HRP or CPS primers. This strain was originally weakly virulent and mucoid when it was isolated in 1976. At that time, it may have had a defective hrp cluster and then lost part of the cps cluster in storage. The primers also worked well with mixed cultures and plant material. The PCR assay detected 20 CFU using cultured cells and 200 CFU from infected plant tissue. This sensitivity compares favorably with that of ELISA $\left(2 \times 10^{4}\right.$ $\mathrm{CFU} / \mathrm{g}$ of seed; 22$)$ and LCR $\left(1.9 \times 10^{3}\right.$ $\mathrm{CFU} / \mathrm{g}$ of plant tissue or $1.0 \times 10^{4} \mathrm{CFU} / \mathrm{ml}$ from a culture; 30 ). Moreover, interference by plant compounds did not seem to be a problem; the primers were able to detect $P$. stewartii in fresh lesions and gave no false reactions with samples from healthy corn plants or extracts from corn seed. The four primer pairs infrequently gave nonspecific bands with closely related species. It is possible that the stringency of the reaction could be further adjusted to eliminate the few weak reactions that we got with several strains of $P$. ananas and one of $P$. agglomerans using the ITS primers. PCR therefore appears to be a more convenient and reliable way to identify $P$. stewartii than pathogenicity tests and many deterministic tests.

PFGE analysis of $P$. stewartii revealed many common bands among strains from different geographic regions. The genome of $P$. stewartii strains seems to be highly conserved (similarity from 60 to $100 \%$ ) based on these common gene fragments. PFGE also easily distinguished $P$. stewartii from other Pantoea and Erwinia spp. For example, the PFGE pattern of $P$. agglomerans pv. herbicola strain Eh7/95 is completely different from that of $P$. stewartii. On the other hand, there was sufficient divergence in the PFGE profiles to differentiate between $P$. stewartii strains from different geographic regions, so that PFGE also may be a useful tool for population genetics and epidemiological studies.

\section{ACKNOWLEDGMENTS}

We thank S. A. Miller and P. A. Abassi for advice and the initial evaluation of the CPS and HRP primers.

\section{LITERATURE CITED}

1. Bereswill, S., Bugert, P., Bruchmüller, I., and Geider, K. 1995. Identification of Erwinia amylovora by PCR with chromosomal DNA. Appl. Environ. Microbiol. 61:2636-2642.

2. Bereswill, S., Pahl, A., Bellemann, P., Zeller, W., and Geider, K. 1992. Sensitive and species-specific detection of Erwinia amylovora by polymerase chain reaction analysis. Appl. Environ. Microbiol. 58:3522-3526.

3. Bernhard, F., Schullerus, D., Bellemann, P., Nimtz, M., Coplin, D. L., and Geider, K. 1996. Genetic transfer of amylovoran and stewartan synthesis between Erwinia amylovora and Erwinia stewartii. Microbiology 142:1087-1096.

4. Blakemore, E. J. A., Law, J. R., and Reeves, J. C. 1999. PCR identification of Erwinia stewartii and its comparison with two other methods. Seed Sci. Technol. 27:385-396.

5. Blakemore, E. J. A., Reeves, J. C., and Ball, S. F. L. 1992. Polymerase chain reaction used in the development of a DNA probe to identify Erwinia stewartii, a bacterial pathogen of maize. Seed Sci. Technol. 20:331-335.

6. Block, C. C., Hill, J. H., and McGee, D. C. 1998. Seed transmission of Pantoea stewartii in field and sweet corn. Plant Dis. 82:775780 .

7. Block, C. C., Hill, J. H., and McGee, D. C. 1999. Relationship between late-season severity of Stewart's Bacterial Wilt and seed infection in maize. Plant Dis. 83:527-530.

8. Breitenstein, S., Tümmler, B., and Römling, U. 1995. Pulsed field gel electrophoresis of bacterial DNA isolated directly from patients' sputa. Nucleic Acids Res. 23:722-723.

9. Bugert, P., and Geider, K. 1995. Molecular analysis of the ams operon required for exopolysaccharide synthesis of Erwinia amylovora. Mol. Microbiol. 15:917-933.

10. Coplin, D. L, Frederick, R. D., and Majerczak, D. R. 1992. New pathogenicity loci in Erwinia stewartii identified by random Tn5 mutagenesis and molecular cloning. Mol. Plant-Microbe Interact. 5:266-268.

11. Coplin, D. L., Frederick, R. D., Majerczak, D. R., and Tuttle, L. D. 1992. Characterization of a gene cluster that specifies pathogenicity in Erwinia stewartii. Mol. Plant-Microbe Interact. 5:81-88.

12. Coplin, D. L., and Kado, C. I. 2000. Pantoea. Pages 73-83 in: Laboratory Manual for the Identification of Plant Pathogenic Bacteria Third ed. N. Schaad, J. Jones, and W. Chun, eds. American Phytopathological Society Press, St. Paul, MN.

13. Coplin, D. L., and Majerczak, D. R. 1990 Extracellular polysaccharide genes in Erwinia stewartii: directed mutagenesis and complementation analysis. Mol. Plant-Microbe Interact. 3:286-292.

14. Coplin, D. L., Majerczak, D. R., Bugert, P., and Geider, K. 1996. Nucleotide sequence analysis of the Erwinia stewartii cps gene cluster for synthesis of stewartan and comparison to the Erwinia amylovora ams cluster for synthesis of amylovoran. Acta Hortic. 411:251-257.

15. Coplin, D. L., Rowan, R. G., Chisholm, D. A., and Whitmoyer, R. E. 1981. Characterization of plasmids in Erwinia stewartii. Appl. Environ. Microbiol. 42:599-604.

16. Dye, D. W. 1963. The taxonomic position of Xanthomonas stewartii (Erw. Smith 1914) Dowson 1939. N. Z. J. Sci. 6:495-506.

17. Egel, D. S., Graham, J. H., and Stall, R. E . 1991. Genomic relatedness of Xanthomonas campestris strains causing diseases of citrus. Appl. Environ. Microbiol. 57:2724-2730.

18. Falkenstein, H., Bellemann, P., Walter, S., Zeller, W., and Geider, K. 1988. Identification of Erwinia amylovora, the fireblight pathogen, by colony hybridization with DNA from plasmid pEA29. Appl. Environ. Microbiol. 54:2798-2802.

19. Frederick, R. D., Ahmad, M., Majerczak, D. R., Arroyo-Rodríguez, A. S., Manulis, S., and Coplin, D. L. 2001. Genetic organization of the Pantoea stewartii subsp. stewartii hrp gene cluster and sequence analysis of the $h r p A, h r p C, h r p N$ and wtsE operons. Mol. Plant-Microbe Interact. 14:1213-1222.

20. Frederick, R.D., Majerczak, D. R., and Coplin, D. L. 1993. Erwinia stewartii wtsA, a positive regulator of pathogenicity gene expression, is similar to Pseudomonas syringae pv. phaeolicola HrpS. Mol. Microbiol. 9:477-485.

21. Kim, W.-S., Gardan, L., Rhim, S.-L., and Geider, K. 1999. Erwinia pyrifoliae sp. nov., a novel pathogen that affects Asian pear trees (Pyrus pyrifolia Nakai). Int. J. Sys. Bacteriol. 49:899-906.

22. Lamka, G. L., Hill, J. H., McGee, D. C., and Braun, E. J. 1991. Development of an immunosorbent assay for seedborne Erwinia stewartii in corn seeds. Phytopathology 81:839-846.

23. Leblond, P., Bedenbach, M., and Cullum. J. 1993. Physical map of the Streptomyces lividans 66 genome and comparison with that of the related strain Streptomyces coelicolor A3(2). J. Bacteriol. 175:3422-3429.

24. Mergaert, J., Verdonck, L., and Kersters, K. 1993. Transfer of Erwinia ananas (synonym, Erwinia uredovora) and Erwinia stewartii to the genus Pantoea emend. as Pantoea ananas (Serrano 1928) comb. nov. and Pantoea stewartii (Smith 1898) comb. nov., respectively, and description of Pantoea stewartii subsp. indologenes subsp. nov. Int. J. Syst. Bacteriol. 43:162-173.

25. Michener, P. M., Pataky, J. K., and White, D. G. 2002. Transmission of Erwinia stewartii from plants to kernels and reactions of corn hybrids to Stewart's wilt. Plant Dis. 86:167 172.

26. Mor, H., Manulis, S., Zuc, M., Nizan, R. Coplin, D. L., and Barash, I. 2001. Genetic organization of the $h r p$ gene cluster and 
dspAE/BF operon in Erwinia herbicola pv. gypsophilae. Mol. Plant-Microbe Interact. 14:431-436.

27. Nei, M., and Li, W.-H. 1972. Mathematical model for studying genetic variations in terms of restriction endonucleases. Proc. Natl. Acad. Sci. USA 82:5078-5082.

28. Pepper, E. H. 1967. Stewart's Bacterial Wilt of Corn. American Phytopathological Society.
St. Paul, MN.

29. Wilson, W. J., and Dillard, H. R. 1999. Assessment of phenotypic variability in Erwinia stewartii based on metabolic profiles. Plant Dis. 83:114-118.

30. Wilson, W. J., Wiedmann, M., Dillard, H. R., and Batt, C. A. 1994. Identification of Erwinia stewartii by a ligase chain reaction assay. Appl. Environ. Microbiol. 60:278-284.
31. Zhang, Y., and Geider, K. 1997. Differentiation of Erwinia amylovora strains by Pulsed Field Gel Electrophoresis. Appl. Environ. Microbiol. 63:4421-4426.

32. Zhang, Y., Merighi, M., Bazzi, C., and Geider, K. 1998. Genomic analysis by Pulsed-Field Gel Electrophoresis of Erwinia amylovora strains from the Mediterranean region including Italy. J. Plant Pathol. 80:225-232.

\section{ERRATUM / Volume 86, Number 3, 2002}

In the article "Identification of Pantoea stewartii subsp. stewartii by PCR and Strain Differentiation by PFGE" by David L. Coplin, Doris R. Majerczak, Yongxiang Zhang, Won-Sik Kim, Susanne Jock, and Klaus Geider, pages 304-311, on page 305, column 3, the last sentence should read "After 35 cycles ( 1.5 to $2 \mathrm{~h}$ ), the PCR product was separated on a $1 \%$ agarose gel $(1.5$ to $2 \mathrm{~h}$ at $1.5 \mathrm{~V} / \mathrm{cm})$, stained with ethidium bromide, and photographed under UV light." 